\title{
Use of Currency Derivatives in India
}

\section{5}

Ms. Sheetal Thomas

Author and Accredited Management Teacher (AIMA)

\section{Abstract}

The introduction of currency derivatives in India was done a decade back and from then on there have been many changes that have been implemented in the trading system in this regard. The paper gives a glimpse of derivatives in general and currency derivatives in particular. It aims to assess the development of currency derivatives in India. To study the growth of the currency derivatives, the number of contracts traded, trading volume and open interest at NSE are studied. The period of study conducted is from 2008-2009 to 2016-17. It is hoped that the currency derivatives market will develop faster and it will be a good choice for all the market participants in the near future and it will find its way in the Indian economy. This paper also explores the factors which determine the usage of currency derivatives by Indian Companies. One of the objectives is to know the development patterns of currency derivatives in India with respect to National Stock Exchange (NSE).

Keywords: currency futures, currency options, open interest, volume traded.

\section{Introduction}

Currency derivatives have had a fruitful period in India. Though it took more than three decades from the time currency futures was introduced at CME, to make its mark in Indian trading sector. Today the exchange traded currency segment in India is stable, growing and powered by the increasing involvement of hedgers and other market participants.

\section{Concept of Derivatives}

The term 'derivatives', refers to a broad class of financial instruments which mainly include options andfutures. These instruments derive their value from the price and other related variables of the underlying asset. They do not have worth of their own and derive their value from the claim they give to their owners to own some other financial assets or security. A simple example of derivative is cocoa butter, which is derivative of cocoa bean. The price of cocoa butter depends upon price of cocoa bean, which in turn depends upon the demand and supply of cocoa bean. The general definition of derivatives means to find the underlying value of an asset. Derivatives can be better understood by dividing into two as a derived function and a derivative instrument. A derived function is the result of mathematical differentiation; the instantaneous change of one quantity relative to another; $\mathrm{df}(\mathrm{x})$ / $\mathrm{dx}$, while a derivative instrument is a financial instrument whose value is based on another security,(linguistics) a word that is derived from another word; 'electricity' is a derivative of 'electric'. The asset underlying a derivative may be commodity or a financial asset. Derivatives are those financial instruments that derive their value from the other assets. For example, the price of gold to be delivered after two months will depend, among so many things, on the present and expected price of this commodity. 


\section{Meaning of Currency Derivative}

Currency Derivatives are Future and Options contracts which one can buy or sell specific quantity of a particular currency pair at a future date. It is similar to the Stock Futures and Options but the underlying happens to be currencypair. Currency Pairs are USD-INR, EUR-INR, GBPINR and JPY-INR (Indian Rupee (INR), US Dollars (USD), Euro (EUR), Great Britain Pound (GBP) and Japanese Yen (JPY)). In other words currency derivatives are complex financial instruments which are traded over - the - counter (OTC) and this is a collective term used for futures, forwards and swaps. Currency derivatives are used for hedging. This hedging involves a future payment or receipt in a foreign currency.

\section{Historical Back Ground of Currency Derivatives}

Currency derivative are introduced in The Chicago Mercantile Exchange (CME) in the year of 1972. The FX contract capitalized on the U.S. abandonment of the Bretton woods agreement, which had fixed world exchange rates to a gold standard after World War II. The abandonment of the Bretton woods agreement resulted in currency values being allowed to float increases the risk of doing a business, by creating another market. The concept of Currency at CME was revolutionary, \& gained credibility through endorsement of Nobel-prize-winning economist Milton Friedman. CME offered 41 individual FX futures \& 31 , options contracts on 19 currencies. The traders of CME FX futures are a diverse group that includes multinational corporations, hedge funds, commercial banks, investment banks, financial managers, commodity trading advisors and individual investors. They trade in order to transact business hedge against unfavourable changes in currency rates or to speculate on exchange rate fluctuations.

\section{Types of Currency Derivatives}

Currency forwards: A currency forward is an agreement between two parties where both the parties agreed to buy/sell an underlying asset at a predetermined price in future. This involves future payment or receivable an unknown foreign exchange rate.
Currency futures: A futures contract is a standardized contract, traded on an exchange, to buy or sell a certain underlying asset or an instrument at a certain date in the future, at a specified price. When the underlying is an exchange rate, the contract is termed a "currency futures contract".

Currency options: A currency option is a contract giving the option purchaser (the buyer) the right, but not the obligation, to buy or sell a fixed amount of foreign exchange at a fixed price per unit for a specified time period.

Currency swaps: A currency swap is an agreement between two parties to exchange cash flows in two different currencies. The swap consists of interest rate differentials between currencies.

\section{Use of currency derivatives}

According to a study conducted on currency derivatives by Manoj Anand, K P Kaushik September, 2008 at IIM-B it was found that most of the firms that use currency derivatives have a clear documented foreign exchange risk management plans, policies orprogrammes. The study further found that transaction exposure as a foreign currency risk was most critical for the firms, followed by translation exposure and economic exposure. The major objectives of using derivatives were:

\section{For hedging risk}

- Arbitrage and

- Price discovery

Speculation as an objective of using foreign currency derivatives was the least preferred.

To reduce volatility in profits after tax and cash flows' and 'to reduce the cost of capital and thus increase firm value' on one side of the pole and 'to reduce risks faced by management' on the other side of the pole were found to be the major motivations of the firms using foreign currency derivatives in India. Firm characteristics such as high degree of debt ratio and ESOPs usage influence use of foreign currency derivatives in India. 


\section{Currency Futures - An alternative to Over-The- Counter}

Currency futures market has become an alternative platform for people using the OTC market. The companies having lesser forex requirement does not get limits to book forward contracts or the brokerage charged by banks is very high. Thus these corporates can use currency futures market to hedge their exposures as they can book the smallest amount of say $\$ 1000$ in this market and brokerage charged is same irrespective of the amount. One of the disadvantages of OTC market is that the maximum permissible period of booking is 1 month option period. This is mitigated by hedgers by booking theirexposure for the first month in currency futures market, roll it overnear the month end and cancel the contract on actual delivery to their bank.

Corporates have now found that they can hedge their exposure though currency derivative market, this helps them in availing better prices and they can hedge for smaller quantity with options. Corporates can also use this platform for cost reductionas there is no restriction on plain selling of options in exchange traded derivative segment.Currency Futures and derivatives egment on exchanges have another advantage of less documentation after execution of trades.

Table-1 Business Growth in CD Segment

\begin{tabular}{|l|l|l|l|l|}
\hline \multirow{2}{*}{ Year } & \multicolumn{2}{|l|}{ Currency Futures } & \multicolumn{2}{l|}{ Currency Options } \\
\cline { 2 - 5 } & No of Contracts & Turnover (in Rs. Cr.) & No of Contracts & Notional Turnover (in Rs.Cr.) \\
\hline $2008-09$ & $3,26,72,768$ & $1,62,272.43$ & - & - \\
\hline $2009-10$ & $37,86,06,983$ & $17,82,608.04$ & - & - \\
\hline $2010-11$ & $71,21,81,928$ & $32,79,002.13$ & $3,74,20,147$ & $1,70,785.59$ \\
\hline $2011-12$ & $70,13,71,974$ & $33,78,488.92$ & $27,19,72,158$ & $12,96,500.98$ \\
\hline $2012-13$ & $68,41,59,263$ & $37,65,105.33$ & $27,50,84,185$ & $15,09,359.32$ \\
\hline $2013-14$ & $47,83,01,579$ & $29,40,885.92$ & $18,18,90,951$ & $10,71,627.54$ \\
\hline $2014-15$ & $35,55,88,963$ & $22,47,992.34$ & $12,50,75,731$ & $7,75,915.32$ \\
\hline $2015-16$ & $40,97,59,364$ & $27,49,332.96$ & $26,38,23,800$ & $17,52,552.62$ \\
\hline $2016-17$ & $32,19,59,121$ & $22,17,344.49$ & $30,73,56,564$ & $20,83,898.43$ \\
\hline
\end{tabular}

Instances such as hiding the trades from top management and blowing out of proportion of hedge books are also prevented due to daily Mark to Market mechanism. Another difficulty with OTC market is that it is completed primarily over the phone. This hinders the execution of deals as there may be congestion of phone lines or nonavailability of price in the market. While for Currency Futures and Derivatives segment all exchanges is online system driven hence better execution of trades is possible.

Exchanges have put in place a comprehensive risk management system, which is constantly upgraded to pre-empt marketfailures. The Clearing Corporation ensures that trading member obligations are commensurate with their net worth. Mark to market margin on daily basis ensures that the client position does not blow out of proportion.NSE is one of the major stock exchanges in India. As mentioned earlier the Indian markets have shown a significant growth both in terms of volumes and numbers of contracts. The equity derivative market in India is expected to grow at an explosive rate in the coming times. NSE alone accounts more than $90 \%$ of the derivatives trading in Indian markets. The Currency Derivatives segment at NSE commenced operations on August 29, 2008 with the launch of currency futures trading in US Dollar-India Rupee (USD-INR).

(Source: Compiled from NSE) 
The trading activity in currency futures and options has been seeing a bounding growth. Table -1 provides the glimpse of the business growth in $C D$ segment. It can be found that the total turnover of currency futures in the year 200809 was Rs $1,62,272.43$ crore and increased by $1366.43 \%$ to Rs $22,17,344.49$ crore in 2016 17. Total number of contracts traded during 2008 -09 were Rs $3,26,72,768$ while it was Rs $32,19,59,121$ in 2016-17. The total turnover of currency options in the year 2010-11 was Rs $1,70,785.59$ crore and increased by $1220.18 \%$ to Rs $20,83,898.43$ crore in $2016-17$. Total number of contracts traded during $2010-11$ were Rs $3,74,20,147$ while it was Rs $30,73,56,564$ in 2016-17. The average daily turnover during this period for CD is RS 14,609.62 crore.

Figure 1

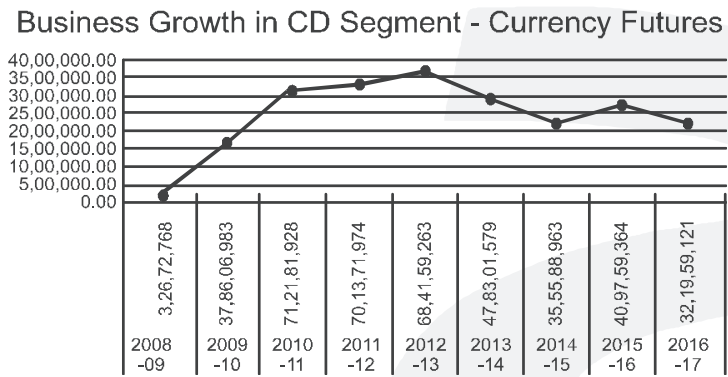

(Source: Compiled from NSE)

The figure-1 represents turnover in crores on vertical axis and number of contracts on horizontal axis. It can be found that there has been period of dips in the currency future traded especially in years 2014-15 and 2016-17.

Figure 2

Business Growth in CD Segment - Currency Options

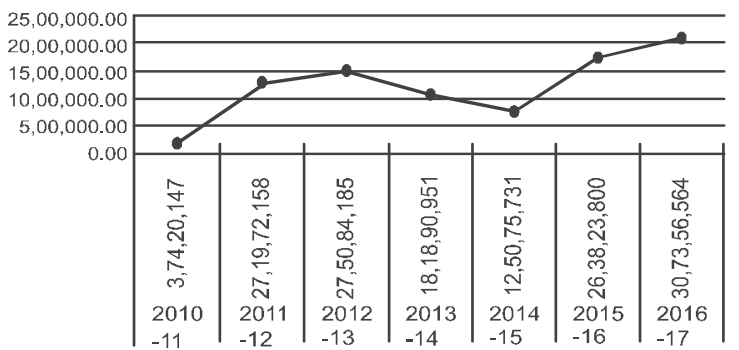

(Source: Compiled from NSE)

The figure-2 represents turnover in crores on vertical axis and number of contracts on horizontal axis for currency options. There has been a noticeable growth in currency options since last 2 years.

Currency Derivative Trade Statistics for the month of January 2017

The currency pair wise open interest for USD INR is $96.78 \%$ with a turnover of $93.34 \%$.

Figure-3

\section{Currency pair wise open Interest}

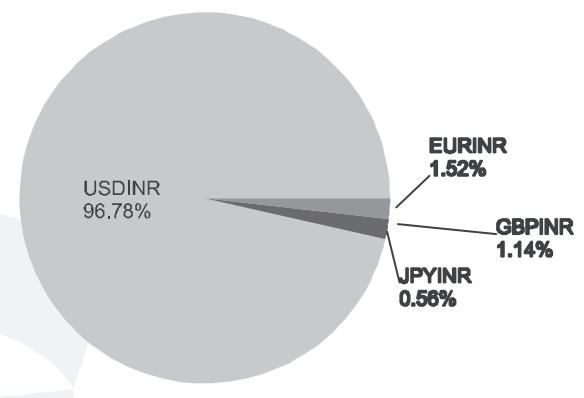

Figure-4

Currency pair wise turnover

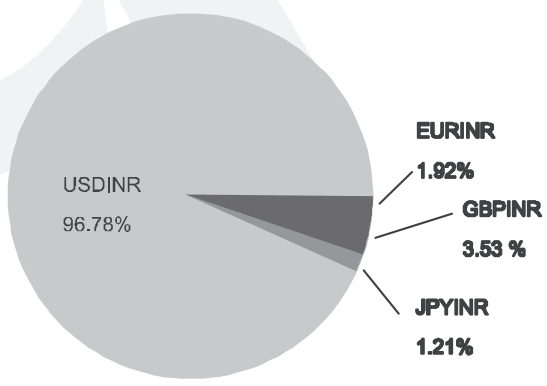

(Source: NSE- Market Pulse January 2017)

Open Interest is the total number of outstanding contracts that are held by market participants at the end of the day. It can also be defined as the total number of futures contracts or option contracts that have not yet been exercised, expired, or fulfilled by delivery. Open interest, or the total number of open contracts on a security, 
is often used to confirm trends and trend reversals for Futures and Options contracts. Open interest measures the flow of money into the futures market. For each seller of a futures contract there must be a buyer of that contract. Thus a seller and a buyer combine to create only one contract. Therefore, to determine the total open interest for any given market we need only to know the totals from one side or the other, buyers or sellers, not the sum of both. The open interest position that is reported each day represents the increase or decrease in the number of contracts for that day, and it is shown as a positive or negative number.

Table- 2 shows the relationship between the price and open interest and the market trend that it follows.

\section{Table-2}

\section{Relationship between the price and open interest}

\begin{tabular}{|l|l|l|}
\hline Price & Open Interest & Interpretation \\
\hline Increasing & Increasing & Market is Strong \\
\hline Increasing & Decreasing & Market is Falling \\
\hline Decreasing & Increasing & Market is Weak \\
\hline Decreasing & Decreasing & Market is Improving \\
\hline
\end{tabular}

(Source: Compiled through various reading material)

\section{Conclusion}

Currency derivatives market has now become stable in India. It has started attracting bigger corporates and thus would be seeing increased level of activity. It provides benefits to the participating parties and is here to stay along with the OTC market. Improving the position of currency futures and derivatives market will support Indian Banking System as a risk mitigation tool. Further currency futures market can introduce more currency pairs for other market participants. Currency option market should also introduce option in other cross currencies, this introduction of variety of currencies and contracts will increase the depth and liquidity in this market.

\section{References:}

Ameer, R., Mohd Isa, R. B., \& Abdullah, A. B. (2011). A survey on the usage of derivatives and their effect on cost of equity capital. The Journal of Derivatives, 19(1), 56-71.

Banking and Finance Digest (2012), FCCI, Issue 10

E.V.P.A.S.Pallavi (2015)"A New Era of Currency Derivatives Market in India"IOSR Journal of Economics and Finance (IOSR-JEF)e-ISSN: 2321-5933, p-ISSN: 2321-5925. Volume 6, Issue 3. Ver. III (May.-Jun. 2015), PP 36-40

Geczy; Minton and Schrand (1997) "Why Firms Use Currency Derivatives" The Journal of Finance, Vol. 52, No. 4. (Sep., 1997), pp. 13231354.

Nissar A. Barua and Devajit Mahanta(2012) "Indian Commodity Derivatives Marketand Price Inflation" IOSR Journal of Business and Management (IOSRJBM) ISSN: 2278487XVolume 1, Issue 6 (July-Aug. 2012), PP 45-59

Shalini H S and Raveendra P V "A Study of Derivatives Market in India and its Current Position in Global Financial Derivatives Markets"IOSR Journal of Economics and Finance (IOSR-JEF)e-ISSN: 2321-5933, p-ISSN: 23215925.Volume 3, Issue 3. (Mar-Apr. 2014), PP 25-42

Raghavendra RH, Velmurugan PS (2014),'The Determinants of Currency Hedging in Indian IT Firms.' J Bus Fin Aff 3: 125. doi:10.4172/21670234.1000125

NSE Market Pulse January 2017

NSE Currency Derivatives Brochure www.nseindia.com 